\title{
PENGEMBANGAN E-MODULE MENGGUNAKAN APLIKASI 3D PAGEFLIP PROFESSIONAL PADA POKOK BAHASAN ASAM DAN BASA
}

\section{Sindy Oktavia*, Sri Haryati, Erviyenni Erviyenni}

Program Studi Pendidikan Kimia, Fakultas Keguruan dan Ilmu Pendidikan Universitas Riau, Kampus Binawidya KM 12,5, Pekanbaru 28293, Riau, Indonesia

\section{Informasi Artikel}

\section{Sejarah Artikel:}

Diterima: 25-08-2020

Disetujui : 4-01-2021

Dipublikasikan: 27-01-2020

\section{Keywords:}

E-module,

3 pageFlip professional,

learning achievement, acid and base.

\begin{abstract}
A b s t r a k
Pembelajaran abad 21 identik dengan penggunaan teknologi dalam proses pembelajaran sehingga pembelajaran menjadi inovatif, menarik, dan berkualitas. Tujuan penelitian ini yaitu mengembangkan e-module menggunakan aplikasi 3D PageFlip Professional pada pokok bahasan asam dan basa dengan kategori valid berdasarkan aspek substansi isi, desain pembelajaran, komunikasi visual, dan pemanfaatan software. Prosedur pengembangan yang digunakan dalam penelitian ini yaitu merujuk pada model pengembangan ADDIE (Analyze, Design, Develop, Implementation, Evaluate). Instrumen penelitian berupa lembar validasi yang dinilai oleh dua orang ahli materi dan dua orang ahli media. Hasil yang diperoleh dari analisis data validasi pada aspek substansi isi, desain pembelajaran, komunikasi visual dan pemanfaatan software berturut-turut sebesar 94,44\%, 94,917\%, 94,318\%, dan 95,83\% dengan kriteria valid. $E$ module yang telah memperoleh kriteria valid menurut validator diuji respon kepada tiga orang guru bidang studi kimia dan 20 orang peserta didik. Hasil persentase respon peserta didik sebesar 92,596\% dengan kriteria sangat baik, dan hasil persentase respon guru sebesar 95,58\%. Kesimpulan yang diperoleh dari hasil analisis data tersebut bahwa dihasilkan e-module menggunakan aplikasi 3D PageFlip Professional yang valid dan dapat digunakan dalam proses pembelajaran kimia tingkat SMA pada pokok bahasan Asam dan basa.
\end{abstract}

\section{A b s tract}

The 21st century learning is identical with use of technology in the learning process so that learning becomes innovative, interesting, and have a quality. The purpose of this study is to develop e-module using $3 D$ Page Flip Professional application on the subject of acid and base with a valid category based on the aspects of content substance, learning design, visual communication, and software utilization. The development procedure that used in this study refers to the development model ADDIE (Analyze, Design, Develop, Implementation, and Evaluate). The instrument that used for this research is a validation sheet which was assessed by two material experts and two media experts. The results obtained from the validation data analysis on the aspects of content substance, learning design, visual communication, and software utilization successively were $94.44 \%, 94.917 \%, 94.318 \%$, and $95.83 \%$ with valid criteria. E-module that has obtained valid criteria according to the validator tested for responses to three chemistry teachers and 20 
students. The percentage result of student's responses was $92.596 \%$ with very good criteria, and the percentage result of teacher's responses was $95.58 \%$. The conclusion of the result of data analyzed that the e-module was produced with $3 D$ Pageflip Professional application valid and can be used to chemistry learning process in the high school level on the subject of acid and base.

(C) 2021 JPK UNRI. All rights reserved

*Alamat korespondensi:

e-mail: sindyoktavia94@gmail.com (SO), sriharyatipku74@gmail.com (SH)

No. Telf: -

\section{PENDAHULUAN}

Memasuki abad 21, perkembangan teknologi dan informasi yang pesat berdampak dalam perbaikan dan peningkatan kualitas pembelajaran. Menurut Aprida dan Dasopang (2017), pembelajaran mempunyai arti yaitu proses interaksi yang terjadi antara peserta didik baik dengan guru, bahan ajar, metode pembelajaran, strategi pembelajaran, maupun sumber belajar di dalam lingkungan belajar. Tuntutan dari pembelajaran abad 21 di era revolusi industri 4.0 yaitu guru dan peserta didik bersama-sama membangun pembelajaran yang inovatif, kreatif, dan memanfaatkan teknologi secara optimal. Menurut Rusman (2015), guru sebagai fasilitator dan mediator yang menyediakan pembelajaran dengan berbagai inovasi teknologi sedangkan peserta didik berperan sebagai penentu keberhasilan dalam proses pembelajaran sekaligus pengguna fasilitas yang telah disediakan oleh guru tersebut.

Dahulunya guru menggunakan bahan ajar dalam bentuk cetak, namun dengan perkembangan IPTEK dalam pembelajaran abad 21 maka terbukalah kesempatan bagi guru dan peserta didik untuk beralih menggunakan bahan ajar berbasis teknologi komputer. Salah satu bahan ajar yang banyak dimanfaatkan dalam pembelajaran dan dapat dikembangkan dengan bantuan teknologi komputer yaitu modul pembelajaran.

Hasil wawancara yang dilakukan penulis dengan guru bidang studi kimia di SMA Negeri 2 Pekanbaru di dapatkan informasi bahwa guru pernah menggunakan e-module dengan format PDF dan Power Point. Isi dari e-module tersebut yaitu materi pembelajaran dalam satu kompetensi dasar (KD). Namun dalam pembuatannya belum mengikuti pedoman penulisan e-module dan dalam segi tampilan terkesan monoton serta belum interaktif. Hal ini dikarenakan keterbatasan waktu guru dalam pembuatan e-module, sehingga menyebabkan kurangnya motivasi peserta didik untuk belajar baik dalam proses pembelajaran maupun di luar jam pelajaran secara individu. Berdasarkan kuisioner yang dibagikan kepada peserta didik kelas XI di SMA Negeri 2 Pekanbaru, diperoleh data sebanyak 83,33\% peserta didik menilai penggunaan e-module dengan tampilan yang menarik dapat meningkatkan semangat belajar. Upaya yang dapat dilakukan untuk membuat e-module yang diharapkan khusunya dalam memenuhi tuntutan pembelajaran abad 21 yaitu menggunakan aplikasi 3D PageFlip Professional. Keunggulan dari aplikasi tersebut yaitu dapat menggabungkan teks, video, audio, link, dan gambar dalam satu file serta memberikan tampilan secara tiga dimensi, sehingga e-module menjadi menarik dan dapat memvisualisasikan konsep-konsep yang abstrak menjadi suatu konsep yang nyata (Savira, et al., 2019).

Penelitian terkait pengembangan E-Module menggunakan aplikasi 3D PageFlip Professional pernah dilakukan pada materi hidrokarbon dan memperoleh skor penilaian dari validasi ahli media sebesar 69 dengan kategori sangat baik dan skor penilaian dari uji coba satu-satu sebesar 86\% dengan kriteria sangat baik berdasarkan penelitian Jumiana (2018). Asyhar et al (2015) juga telah mengembangkan e-modul menggunakan software $3 D$ pageflip professional dan diterapkan pada materi ikatan kimia. Seruni et al (2019) telah melaporkan pengembangan e-modul berbasis flip Pdf 
professional pada materi metabolisme lipid. Hasil penelitian ini menunjukkan bahwa modul yang dikembankan memiliki interpretasi yang baik dari aspek materi, Bahasa dan medianya.

Berdasarkan latar belakang yang telah dijelaskan, maka dipandang perlu adanya penelitian terkait pengembangan bahan ajar berupa e-module, sehingga peneliti tertarik melakukan penelitian pengembangan dengan judul Pengembangan e-module menggunakan aplikasi $3 d$ pageflip professional pada pokok bahasan asam dan basa untuk kelas XI tingkat SMA/MA.

\section{METODE PENELITIAN}

Penelitian dilaksanakan di SMA Negeri 2 Pekanbaru. Proses pembuatan e-module dilakukan di Fakultas Keguruan dan Ilmu pendidikan Universitas Riau. Waktu penelitian dimulai pada bulan April hingga Agustus 2020. Proses pengembangan e-module menggunakan aplikasi $3 D$ pageflip professional pada pokok bahasan asam dan basa merujuk pada model pengembangan ADDIE. Menurut Tung (2017), Model pengembangan ADDIE terdiri dari 5 tahap yaitu analyze (analisis), design (desain), develop (pengembangan), implementation (implementasi), dan evaluate (evaluasi). Alur pengembangan e-modul ditunnjukkan pada Gambar 1.

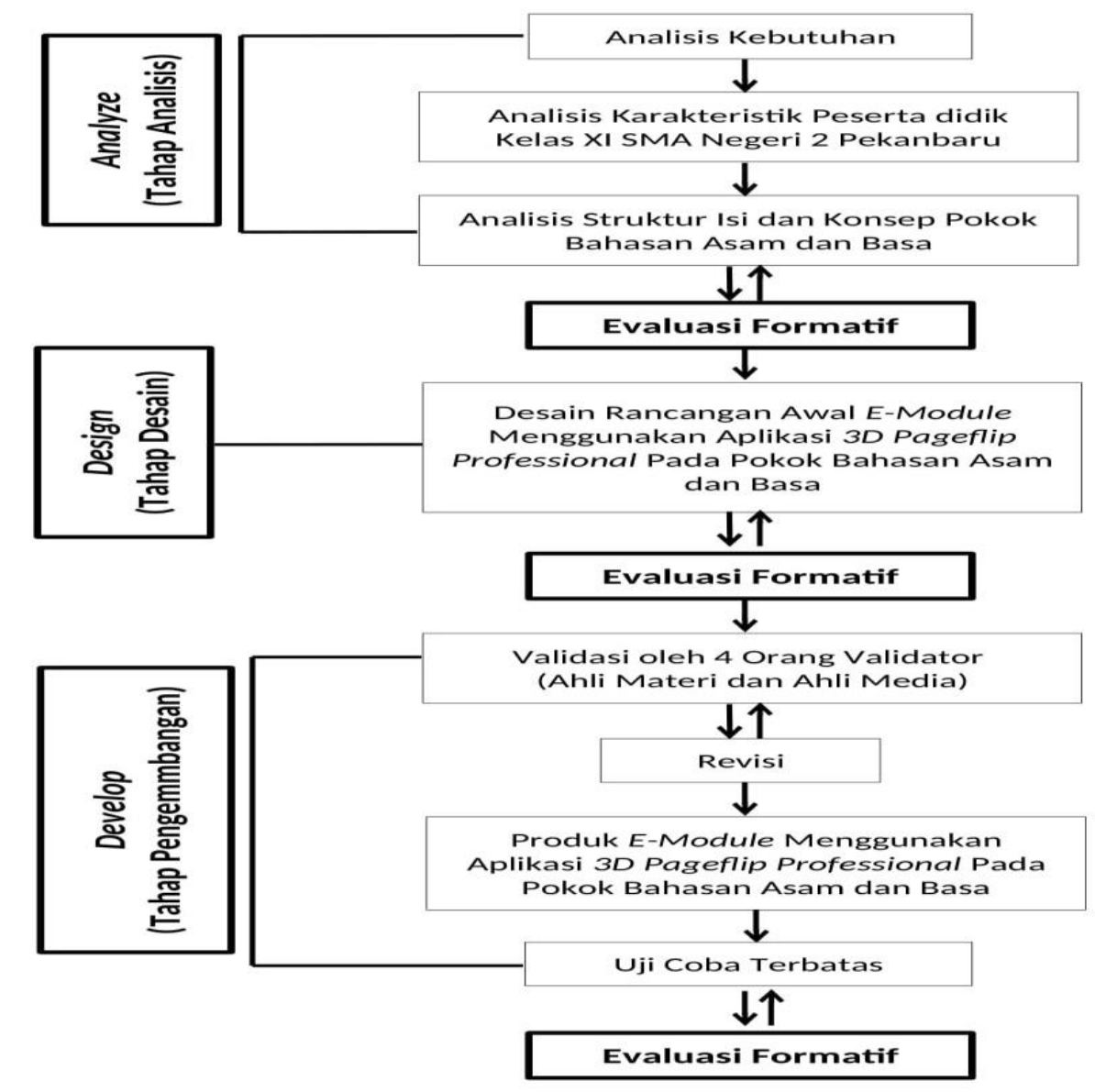

Gambar 1. Alur pengembangan e-module menggunakan aplikasi $3 D$ pageflip professional pada pokok bahasan asam dan basa (Tung, 2017) dengan beberapa modifikasi.

Tahap Implementation tidak dilaksanakan dikarenakan penelitian terbatas untuk menghasilkan produk dengan kategori valid berdasarkan empat aspek penilaian yaitu aspek substansi isi, desain pembelajaran, komunikasi visual, dan pemanfaatan software.

Pada tahap Develop terdiri dari validasi dan uji coba terbatas untuk mengumpulkan data terkait validitas dan uji respon pengguna terhadap e-module menggunakan aplikasi $3 D$ PageFlip 
Professional pada pokok bahasan asam dan basa. Validasi dilakukan oleh dua orang ahli materi dan 2 orang ahli media dengan menggunakan instrumen penelitian berupa lembar validasi dan rubrik validasi. Uji respon pengguna guru maupun peserta didik menggunakan kuisioner respon sebagai instrumen penelitian.

Data yang telah dikumpulkan pada tahap Develop kemudian dianalisis dengan menggunakan teknik tertentu. Anlisis validitas menggunakan persamaan 1:

$$
\text { Persentase }=\frac{\text { Skor yang diperoleh }}{\text { Skor maksimum }} \times 100 \%
$$

Persentase yang didapatkan selanjutnya dapat dikonversi menjadi nilai kualitatif dengan kriteria validitas pada Tabel 1.

Tabel 1. Kriteria validitas

\begin{tabular}{lcc}
\hline No. & Persentase $(\%)$ & Keterangan \\
\hline 1 & $80,00-100$ & Valid \\
2 & $60,00-79,99$ & Cukup Valid \\
3 & $50,00-59,99$ & Kurang Valid \\
4 & $0-49,99$ & Tidak Valid \\
\hline
\end{tabular}

Analisis respon pengguna menggunakan skala Likert dalam bentuk checklist $(\sqrt{ })$ yang berupa skor alternatif pernyataan positif pada Tabel 2 agar diperoleh data kuantitatif.

Tabel 2. Skor Alternatif penyataan positif (Sukardi, 2017)

\begin{tabular}{lcc}
\hline No. & Pernyataan Sikap & Skor \\
\hline 1 & Sangat Setuju (SS) & 4 \\
2 & Setuju(S) & 3 \\
3 & Tidak Setuju (TS) & 2 \\
4 & Sangat Tidak Setuju (STS) & 1 \\
\hline
\end{tabular}

Menurut Ristanti, dkk. (2019), menghitung persentase skor respons pengguna digunakan persamaan (2):

$$
R=\frac{f}{n} \times 100 \%
$$

Dimana, $\mathrm{R}$ adalah persentase nilai respons peserta didik (\%), $\mathrm{f}$ adalah jumlah nilai yang diperoleh dan $\mathrm{n}$ adalah jumlah nilai maksimum. Sementara itu, persentase skor alternatif pernyataan sikap pengguna yang telah diperoleh, selanjutnya dikonversi menjadi nilai kualitatif dengan kriteria respon pengguna pada Tabel 3.

Tabel 3. Kriteria respons pengguna (Rianti et al., 2019)

\begin{tabular}{lcc}
\hline No & NIlai $(\%)$ & Kriteria Respons \\
\hline 1 & $81,25<\mathrm{R} \leq 100$ & Sangat Positif/Sangat Baik \\
2 & $62,5<\mathrm{R} \leq 81,25$ & Positif/Baik \\
3 & $43,75<\mathrm{R} \leq 62,5$ & Kurang positif/Kurang Baik \\
4 & $25<\mathrm{R} \leq 43,75$ & Tidak Positif/Tidak Baik \\
\hline
\end{tabular}




\section{HASIL DAN PEMBAHASAN}

Hasil penelitian pengembangan berupa produk e-module menggunakan aplikasi 3D PageFlip Professional pada pokok bahasan asam dan basa untuk kelas XI tingkat SMA/MA. E-module menggunakan aplikasi 3D PageFlip Professional dirancang dengan baik dan menarik sesuai dengan kebutuhan peserta didik, sehingga dapat digunakan baik dalam proses pembelajaran maupun sebagai bahan ajar mandiri diluar jam pelajaran. Berikut hasil dan pembahasan dari setiap langkah penelitian yang telah dilakukan berdasarkan prosedur pengembangan model ADDIE.

\subsection{Tahap Analisis}

\section{A. Analisis Kebutuhan}

Analisis kebutuhan telah dilaksanakan melalui wawancara kepada guru bidang studi kimia dan pemberian angket kebutuhan kepada peserta didik kelas XI SMA Negeri 2 Pekanbaru. Dari kegiatan tersebut diperoleh informasi bahwa guru telah menggunakan $e$-module dalam format Power Point dan PDF, namun dalam pembuatannya belum interaktif, monoton, dan belum mengikuti pedoman pembuatan e-module. Berdasarkan angket yang diberikan kepada peserta didik, diperoleh data sebanyak 55,56\% peserta didik kurang memahami materi asam dan basa, dan sebayak 83,33\% peserta didik menilai penggunaan e-module dengan tampilan yang menarik dapat meningkatkan semangat belajar.

\section{B. Analisis Karakteristik Peserta Didik}

Pokok bahasan asam dan basa dipelajari oleh peserta didik kelas XI SMA/MA dan pada umumnya berusia 16-17 tahun. Menurut Jean Piaget, perkembangan kognitif anak pada umur 11 tahun hingga dewasa memasuki tahap operasional formal. Ciri-ciri dari tahap ini diperolehnya kemampuan untuk berpikir, menalar, dan menarik kesimpulan dari suatu informasi serta dapat memikirkan kemungkinan yang ada untuk memecahkan suatu persoalan karena telah memiliki kemampuan untuk berpikir kritis (Yusuf, 2016).

\section{Analisis Struktur Isi dan Konsep}

Analisis struktur isi yaitu melakukan analisis kurikulum seperti analisis kompetensi inti dan kompetensi dasar pada pokok bahasan asam dan basa (KD 3.10 dan 4.10). selain itu juga menganalisis indikator pencapaian kompetensi serta tujuan pembelajaran. Analisis konsep menghasilkan konsepkonsep utama pada pokok bahasan asam dan basa yang akan dituangkan ke dalam e-module yang disusun secara sistematis dalam bentuk peta konsep.

\subsection{Tahap Desain}

Hasil tahap Design berupa rancangan awal e-module berupa storyboard yang terdiri dari 1) Cover, 2) Profile, 3) kata pengantar, 4) daftar isi, 5) cara penggunaan e-module, 6) kompetensi dasar, 7) indikator pencapaian kompetensi, 8) tujuan pembelajaran, 9) manfaat $e$-module, 10) peta konsep, 11) uraian materi, 12) selingan, 13) latihan soal, 14) evaluasi, 15) glosarium, 16) referensi, 17) penulis. Tahap Design juga menghasilkan instrumen penelitian berupa lembar validasi, rubrik validasi, kuisioner respon pengguna guru dan peserta didik.

\subsection{Tahap Pengembangan}

\section{A. Validasi $E$-Module}

Tujuan dilakukan validasi untuk mengetahui kelayakan e-module yang dikembangkan dan memperoleh penilaian serta saran validator terhadap e-module menggunakan aplikasi $3 D$ PageFlip Professional pada pokok bahasan asam dan basa. Validasi dilakukan sebanyak dua kali oleh masingmasing validator yang terdiri dari dua orang ahli materi dan dua orang ahli media. Grafik persentase 
skor rata-rata validasi satu dan dua dari keempat aspek penilaian oleh validator ahli disajikan pada Gambar 2.

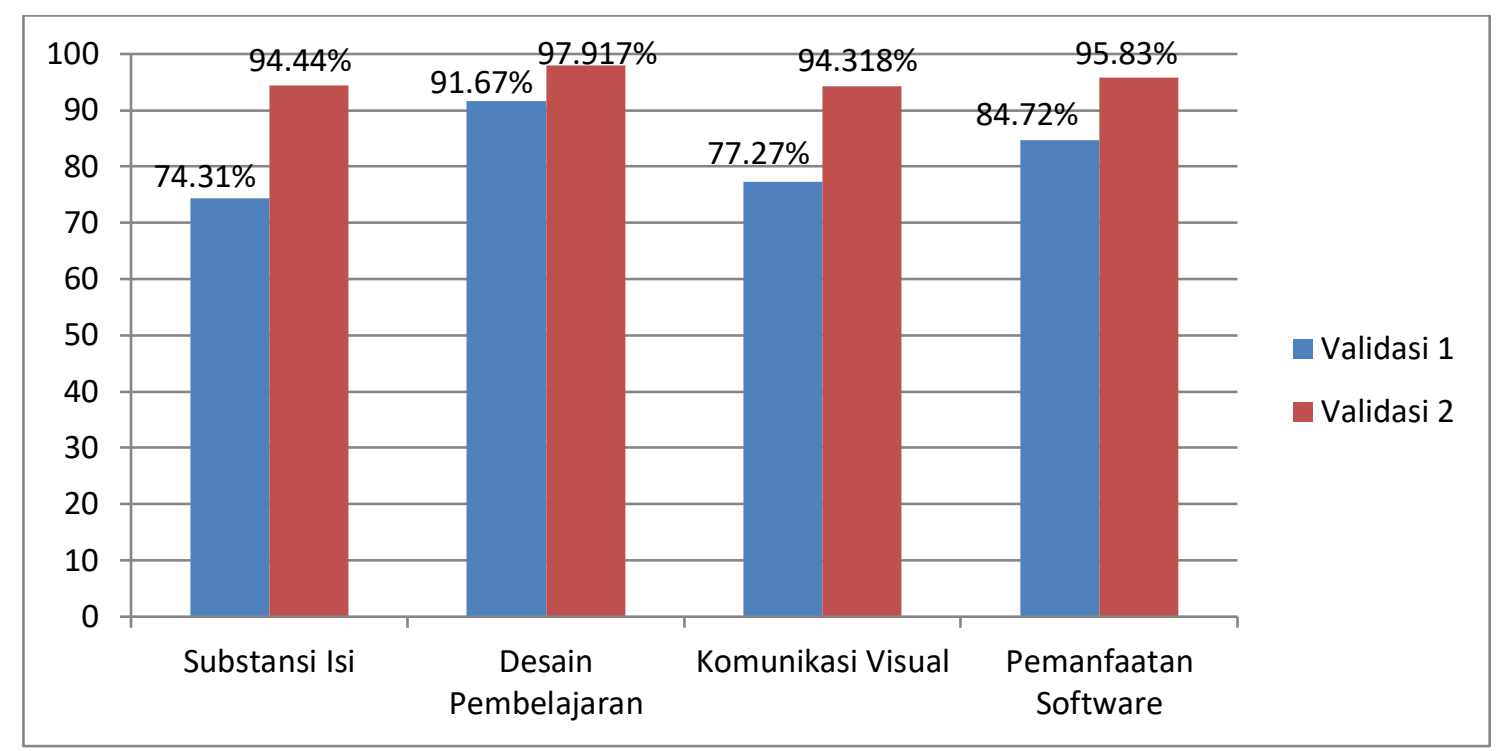

Gambar 2. Nilai rata-rata validasi e-modul

\section{B. Uji Coba Terbatas}

Uji coba terbatas dilakukan untuk mengetahui tanggapan, saran, dan penilaian daru dan peserta didik sebagai pengguna e-module menggunakan aplikasi 3D PageFlip Professional pada pokok bahasan asam dan basa. Uji coba satu-satu dilakukan kepada 3 orang peserta didik untuk mengerjakan e-module,sedangkan uji respon pengguna dilakukan kepada 3 orang guru bidang studi kimia dari SMA Negeri 2 Pekanbaru dan memperoleh persentase skor rata-rata sebesar 95,58\% dengan kriteria sangat baik. Uji respon pengguna juga dilakukan kepada peserta didik sebanyak 20 orang responden dengan teknis peserta didik membaca e-module kemudian diberikan kuisioner respon pengguna dan memperoleh persentase skor rata-rata sebesar 92,596\% dengan kriteria sangat baik.

\subsection{Tahap Evaluasi}

Tahap evaluasi yang dilakukan adalah evaluasi formatif. Evaluasi formatif bertujuan untuk mengevaluasi atau memperbaiki kesalahan yang terdapat pada tiap tahapan, guna menyempurnakan produk e-module yang dikembangkan.

\section{KESIMPULAN DAN SARAN}

\subsection{Kesimpulan}

E-Module menggunakan aplikasi $3 D$ pageflip professional pada pokok bahasan asam dan basa untuk kelas XI tingkat SMA/MA yang dikembangkan melalui prosedur pengembangan model ADDIE telah dinyatakan valid oleh validator ahli materi dan ahli media berdasarkan aspek substansi isi, desain pembelajaran, komunikasi visual, dan pemanfaatan software. Hasil respon pengguna guru dan peserta didik mendapatkan penilaian penilaian dengan kriteria sangat baik.

\subsection{Rekomendasi}

Peneliti merekomendasikan e-module menggunakan aplikasi 3D Pageflip Professional pada pokok bahasan asam dan basa sebagai salah satu bahan ajar kimia dengan mempertimbangkan peralatan pendukung yaitu laptop atau komputer dan peneliti mengharapkan e-module menggunakan aplikasi 3D Pageflip Professional dapat dikembangkan untuk pokok bahasan kimia lainnya. 


\section{DAFTAR PUSTAKA}

Aprida, P., Dasopang, M. D. 2017. Belajar dan Pembelajaran. Jurnal Kajian Ilmu-Ilmu Keislaman 3(2): 333-352.

Asyhar, R., Afrida, Widiastiningsih, R. 2015. Pengembangan e-modul menggunakan software 3d pageflip professional untuk pembelajaran ikatan kimia kelas x SMA Islam Al Falah kota Jambi. Journal of The Indonesian Society of Integrated Chemistry. 7(1): 18-24

Jumiana, M. 2018. Pengembangan E-Modul Menggunakan Program 3D Page Flip Professional Pada Materi Hidrokarbon. Skripsi. Unpublish. Universitas Jambi

Ristanti, V. N. D., Nurmilawati, M., Sulistiyowati, T. I. 2019. Respon Siswa Terhadap Modul Pembelajaran Berbasis SAVI (Somatic, Auditory, Visualitation, Intellegency) Pada Materi Ekosistem di SMAN 1 Papar. Jurnal Biologi dan Pembelajarannya 6(1): 36-38.

Rusman. 2015. Belajar dan Pembelajaran Menggunakan Aplikasi Komputer Mengembangkan Profesionalisme Guru Abad 21. Alfabeta. Bandung

Savira, Y. M., Budi, A. S., Supriyanti, Y. 2019. Pengembangan E-Modul Materi Momentum dan Impuls Menggunakan Aplikasi Process Oriented Guided Inquiry Learning (POGIL) untuk Meningkatkan Kemampuan Berpikir Tingkat Tinggi Siswa SMA Kelas X. Prosiding Seminar Nasional Fisika (E-Journal) SNF VIII: 25-36. Fakultas Matematika dan Ilmu Pengetahuan Alam Universitas Negeri Jakarta. Jakarta

Seruni, R., Munawaroh, S., Kurniadewi, F., Nurjayadi, M. 2019. Pengembangan modul elektronik (emodul) biokimia pada materi metabolisme lipid menggunakan flip pdf professional. JTK:

Jurnal Tadris Kimiya. 4 (1): 48-56

Sukardi. 2015. Metodologi Penelitian Pendidikan Kompetensi dan Praktiknya. Bumi Aksara. Yogyakarta

Tung, K. Y. 2017. Desain Instruksional Perbandingan Model dan Implementasinya. Andi. Jakarta

Yusuf, S. 2016. Psikologi Perkembangan Anak dan Remaja. Remaja Rosdakarya. Bandung 